\title{
Does Ethically-motivated Corporate Social Responsibility Lead to Superior Corporate Financial Performance?
}

\begin{abstract}
Prior research on the relation between corporate social responsibility (CSR) and corporate financial performance (CFP) does not differentiate ethically-motivated and economicallymotivated CSR though qualitative studies suggest that the two may have distinct impact on CFP. Using the financial crisis as a unique identification strategy, this study performs a difference-indifferences analysis to empirically document that ethical CSR firms financially outperform economic CSR firms by 1.4 percentage point and 4.8 percentage point measured by the changes in returns on assets and returns on equity from the pre-crisis to the post-crisis period, respectively. The effect is more pronounced in the employee relations dimension and increasing CSR strengths is more effective than decreasing CSR concerns. The results suggest that the impact of ethicallymotivated CSR on CFP is more positive than that of economically-motivated CSR, which extends the literature on the impact of CSR on CFP and bridges the gap between ethically-motivated CSR and CFP.
\end{abstract}

Keywords: Corporate Financial Performance; Corporate Social Responsibility; Economicallymotivated CSR; Ethically-motivated CSR; Financial Crisis 


\section{Does Ethically-motivated Corporate Social Responsibility \\ Lead to Superior Corporate Financial Performance?}

\section{Introduction}

Firms engaging in corporate social responsibility (CSR) programs generally fall into two camps, namely the ethical CSR camp and the economic CSR camp. The economic CSR firms, largely motivated by the neo-economic theories (Friedman 1970; Milton 1962), hold that the optimal level of CSR should be determined by a cost-benefit analysis to maximize shareholder wealth. Though the view of economic CSR firms presents a "win-win" outcome for society and shareholders, it fuels growing mistrust and skepticism of firms on the accusation of window dressing or greenwashing. Firms in the ethical CSR camp state that CSR is driven by moral imperative and should be engaged for ethical reasons (McGuire 1963; Windsor 2001), but they meet challenges from shareholders for asking corporations to work against their profit-seeking nature.

Recognizing the gap between ethically-motivated CSR and corporate financial performance (CFP), researchers have endeavored to integrate the views of the economic and the ethical CSR firms by exploring the return of CSR to economic and ethical CSR firms (Driver 2006; Windsor 2006). They argue that the two perspectives held by economic and ethical CSR firms are polar-opposites of a conceptual continuum: economic CSR firms restrict themselves to utilitarian ethics concentrating on protection of shareholder wealth while ethical CSR firms define welfare outcomes more broadly to include expanded moral duties in addition to shareholder wealth. Their argument suggests that the objective of ethically-motivated CSR includes and goes beyond CFP, and so ethically-motivated CSR and CFP are not mutually exclusive. 
A large number of studies examine whether and how CSR enhances corporate financial performance (Chang, Oh, \& Messersmith 2013; Godfrey 2005; Godfrey, Merrill, \& Hansen 2009; Hillman \& Keim 2001; Hull \& Rothenberg 2008; Manchiraju \& Rajgopal 2017; McWilliams \& Siegel 2001; Orlitzky, Schmidt, \& Rynes 2003; Wang, Dou, \& Jia 2016), but prior literature is generally silent on the financial gains from CSR for ethical CSR firms, though an increasing number of studies have recognized that motives of CSR engagement influences stakeholders' perception of CSR authenticity (Alhouti, Johnson , \& Holloway 2016; Rekon, Go, \& Calter 2014; Skarmeas \& Leonidou 2013) and firm reputation (Wang and Berens 2015) which in turn affects the outcomes of CSR engagement.

If the impact of ethically- and economically-motivated CSR engagement on CFP could potentially be different, then it is necessary to distinguish between ethically- and economicallymotivated CSR when examining the association between CSR and CFP, without which the distinct real impact of ethically- and economically-motivated CSR remains an open question ${ }^{1}$. Recent research suggests that perceptions of economic usage of CSR weakens the positive impact of CSR on CFP (Jones 1995; Beckman, Colwell, \& Cunningham 2009; Mazutis \& Slawinski 2015), but most of the studies are qualitative or conceptual. This study empirically investigates the effect of CSR on CFP for ethical and economic CSR firms. We posit that CSR could benefit CFP for ethical CSR firms just as for economic CSR firms and the effect of CSR on CFP is more positive for ethical CSR firms than for economic CSR firms.

Because ethical and economic CSR firms are differentiated by their unobservable motives (McWilliams \& Siegel 2011), we draw on the resource-based view (Aragón-Correa \&

\footnotetext{
${ }^{1}$ The objective of the study is to differentiate the impact of CSR on CFP for ethical and economic CSR firms. We do not intend to draw conclusions on the relation between CSR and CFP in general which has been explored extensively in prior literature.
} 
Sharma 2003; Christmann 2000; Russo \& Fouts 1997) and exploit the financial crisis surrounding 2008 as an external shock to firms' resource availability to empirically distinguish firms engaging in CSR for ethical and financial reasons. The resource-based view suggests financially resourceful firm are more likely to engage in and benefit more from CSR engagement. When financial crisis looms, financing is tightened and layoffs occur. Firms must tradeoff between CSR and core business operations with limited resources, making engagement in CSR increasingly costly. Economic CSR firms should see good reasons to axe CSR programs based on the cost-benefit analysis. On the other hand, the financial crisis creates opportunities for socially responsible firms to initiate CSR programs to resolve ethical issues uncovered by the financial crisis, thereby facilitating ethically-motivated CSR regardless of their effect on CFP. Hence, we classify firms improving CSR performance during the financial crisis as ethical CSR firms while those allowing their CSR performance to remain unchanged or even deteriorate as economic CSR firms. CSR performance is measured by a composite CSR index aggregating CSR strengths and concerns rated by MSCI ESG (formerly KLD). To partially overcome the concern about reverse causality and omitted variables (Manchiraju \& Rajgopal 2017), we match each ethical CSR firm in our sample with an economic CSR firm that is similar in a series of financial firm characteristics and CSR performance in the pre-crisis period (i.e., 2006 and 2007) to conduct a difference-in-differences analysis.

A univariate comparison of the ethical and the economic CSR firms show that both samples of firms experience reductions in return on assets $(R O A)$ of over 4 percentage point and reductions in return on equity $(R O E)$ of over 10 percentage point from the pre-crisis period to the crisis period (i.e., 2008 and 2009), suggesting that the ethical CSR firms face similar negative impact of the financial crisis as the economic CSR firms do. ROA of the ethical CSR firms is 
0.23 percentage point higher in the post-crisis period (i.e., 2010 and 2011) than in the pre-crisis period, but the economic CSR firms report post-crisis $R O A$ that is 1.47 percentage point lower than their pre-crisis $R O A$ on average. The results suggest that the ethical CSR firms recover faster than the economic CSR firms following the financial crisis. The analysis regarding $R O E$ depicts a similar picture where $R O E$ of the ethical CSR firms increases but $R O E$ of the economic CSR firms decreases from pre-crisis to post-crisis. The univariate analysis results provide preliminary support to our prediction that the effect of ethically-motivated CSR on CFP is more positive than that of economically-motivated CSR.

Next, we formally investigate the effect of ethically-motivated and economicallymotivated CSR on CFP using multivariate analysis that controls for common factors determining CFP documented in prior literature (Flammer 2015; McWilliams \& Siegel 2000; Waddock \& Graves 1997). We find that the ethical CSR firms' $R O A$ increases 1.40 percentage point more than the economic CSR firms' $R O A$ does from the pre-crisis period to the post-crisis period. The difference is economically significant as it is 28 percent of the mean $R O A$ of the ethical CSR firms in the pre-crisis period. Similarly, the ethical CSR firms' $R O E$ recovers 4.80 percentage point more than the economic CSR firms, which is 43 percent of the mean pre-crisis $R O E$ of the ethical CSR firms. The results provide strong empirical evidence that the effect of ethicallymotivated CSR on CFP is more positive than that of economically-motivated CSR.

The third set of analyses explores the effect of CSR efforts in various dimensions on CFP. Our analyses reveal that CSR engagement in the dimension of employee relations is more beneficial to CFP for ethical CSR firms than for economic CSR firms. Since many firms resort to layoff to cut expenditures during the financial crisis (Dierynck, Landsman, \& Renders 2012; Hall 2016), employees are among the most shocked stakeholders during the financial crisis. Our 
findings are consistent with prior studies documenting that employees can differentiate ethicallyand economically-motivated CSR (e.g., Donia, Ronen, Sirsly, \& Bonaccio 2017; McShane \& Cunningham 2012), and suggest that the firms that dedicate to maintain sound employee relationships even when they are financially challenged are rewarded eventually.

In the prior analyses, we aggregate CSR strengths and concerns to construct the composite CSR index. Prior research suggests that CSR strengths and concerns are distinctly different with "doing good" engendering more positive effects than "avoiding bad" (Chatterji, Levine, \& Toffel 2009; Lin-Hi \& Müller 2013; Zyglidopoulos, Georgiadis, Carroll, \& Siegal 2012). Therefore, we conduct additional analyses that focus on CSR strengths and concerns separately. We find that the ethical CSR firms increasing CSR strengths report greater improvement in CFP from the pre-crisis period to the post-crisis period than the economic CSR firms in terms of both $R O A$ and $R O E$. On the contrary, improvement in $R O A$ and $R O E$ surrounding the financial crisis of the ethical CSR firms reducing CSR concerns is not significantly greater than that of the economic CSR firms. Taken together, the results suggest that ethically-motivated CSR "doing good" are more effective than ethically-motivated CSR "avoiding bad" in enhancing CFP.

Our study contributes to the research on CSR and CFP in three ways. First, the relation between CSR and CFP is an important topic in social accounting research (Chung and Cho 2018). Prior research does not differentiate the effect of CSR on CFP for ethical and economic CSR firms (e.g., Waddock \& Graves 1997; McWilliams \& Siegel 2000) and the few studies that do distinguish the two are largely conceptual or qualitative in nature (e.g., Beckman et al. 2009; Joo, Miller, \& Fink 2019). We exploit the financial crisis surrounding 2008 to conduct a quasiexperiment and empirically show that the effect of CSR on CFP is more positive for ethical CSR 
firms than for economic CSR firms which highlights the importance of differentiating the motivation of CSR engagement in CSR research. Second, we propose and document that the effect of CSR on CFP is more positive for ethical CSR firms than for economic CSR firms. This evidence sheds light on the real impact of ethically-motivated CSR and addresses the major concern regarding the gap between ethically-motivated CSR and CFP. Third, our study contributes to the research integrating ethically- and economically-motivated CSR. Building on the framework that the two perspectives represent the two ends of a continuum (Driver 2006; Windsor 2006), our study confirms that ethically-motivated CSR and CFP are not mutually exclusive and the positive effect of CSR on CFP strengthens as firms move towards the end of ethically-motivated CSR.

\section{Hypothesis Development and Research Design}

\subsection{Ethically-motivated CSR and Economically-motivated CSR}

The lure of the financial benefits incentivizes economic CSR firms to engage in CSR. To these firms, the question whether they should engage in CSR is a question of whether they can find optimal levels of CSR commitment given the costs versus the benefits (Freeman 1984; McWilliams and Siegel 2001). The financial motivation gives rise to the possibility that firms engage in CSR opportunistically for window dressing (Cho, Guidry, Hageman, \& Pattern 2012; Rodrigue et al. 2013) or even as a tool for covering up firms' societal harms or misconducts (Christensen 2015), which suggests economic CSR firms are likely to engage in CSR sporadically when they can gain financially from engagement in CSR. Economic CSR firms are in sharp contrast to ethical CSR firms that engage in CSR for moral imperative (McGuire 1963; Windsor 2001) and to address ethical and social problems regardless of the impact on CFP. As 
such, their commitment to CSR is a reflection of their true selves and not affected by external economic factors.

Researchers have made considerable efforts to bring together the two opposite motives. Windsor (2006) suggests that both ethically- and economically-motivated CSR aim at enhancing general welfare but through different means: economic CSR firms focus on protection of investor property rights and achieving better CFP; on the contrary, ethical CSR firms seek to achieve general welfare by addressing broader moral and social problems; enhancing CFP is not the ultimate objective. In a similar vein, Driver (2006) proposes that a firm's true self is represented by a continuum between egoic and post-egoic conceptions of the organizational self. The egoic self is disconnected with limited consideration of social problems. The post-egoic self is interconnected with extensive consideration of social issues. Consequently, the egoic-self inclines to seek maximization of shareholder wealth and the post-egoic self aims at enhancing the "bigger good". Further, Schneider (2015) argues that economic CSR firms misorder the relation between CSR and CFP. Specifically, the ultimate goal of firms should be sustainable development and both CFP and CSR are means to reach that objective. Economic CSR firms overlook sustainable development and myopically consider improving CFP as the ultimate goal. We note that these frameworks share two common themes. First, both economic and ethical CSR firms are rational agents. They make different decisions regarding CSR engagement because of different objectives of CSR engagement. Second, as ethical CSR firms engage in CSR to achieve "bigger good" including financial and social benefits, ethically-motivated CSR and CFP are not necessarily mutually exclusive. 


\subsection{Corporate Social Responsibility and Corporate Financial Performance}

Multiple theories motivate research on the relation between CSR and CFP. Moskowitz (1972) proposes that commitment to CSR signals managers' social awareness and skills to deliver superior financial results, predicting a positive association between CSR and CFP. The argument receives some support from but is also challenged by empirical studies (Abbott \& Monsen 1979; Cochran \& Wood 1984; Sturdivant \& Ginter 1977).

McWilliams and Siegel (2001) propose that CSR is a product differentiation strategy. Specifically, commitment to CSR offers firms opportunities of innovation and new products which create new demand and the commanding power to charge premium prices. For CSR differentiation to be successful, advertising plays an important role in raising consumers' awareness of products with CSR attributes. Following this line of logic, Hull and Rothenberg (2008) find that CSR improves CFP in low-innovation firms and in industries with little differentiation. Relatedly, Manchiraju and Rajgopal (2017) exploit the regulatory change in India and show that mandatory CSR investment is associated with negative market reactions, but the negative market reactions are attenuated for firms with high levels of advertisement expenditures.

The stakeholder theory opens a new venue for systematically analyzing the benefits of CSR. The stakeholder theory views firms as operating in a nexus of relationships with internal and external stakeholders who provide invaluable resources (Donaldson \& Preston 1995; Freeman 1984). Firms must appropriately address and balance claims of the stakeholders to achieve financial success (Cornell \& Shapiro 1987; Hill \& Jones 1992). Commitment to CSR builds superior reputation and corporate culture which helps firms maintain good relationships with various stakeholders, thereby increasing the efficiency of firms' adaptation to external 
demands. Motivated by the stakeholder theory, Waddock and Graves (1997) document a positive association between CSR and CFP. Hillman and Keim (2001) consider intangible relational competencies as a source of competitive advantage and show that engagement in CSR enhances shareholder value. In a related vein, Godfrey (2005) argues that intangible competencies arising from sound relationships with stakeholders protect firms from negative shocks. Consistent with the argument, Godfrey et al. (2009) employ an event study method and find that participation in CSR attenuates negative market reactions to legal or regulatory actions against firms, suggesting that CSR provides "insurance-like" benefits that grow firms' resilience to negative shocks. Christensen (2015) also finds that corporate accountability reporting weakens negative stock price reactions to high-profile misconduct.

As suggested by the stakeholder theory, CSR engagement helps firms enhance reputation and trust which facilitates stable and lasting relationships with stakeholders (Barney 1991; Russo \& Fouts 1997; Porter \& Kramer 2006). Engagement in CSR must be perceived as authentic and genuine to signal trustworthy (Alhouti et al. 2016; Beckman et al. 2009; Ellen et al. 2006). However, economic CSR firms engage in CSR sporadically only when the narrowly-defined financial benefits outweigh the costs, which itself is a signal of opportunism and a red flag to stakeholders. On the other hand, ethical CSR firms consistently engage in CSR for their genuine belief in its value to the broader society. Jones (1995) suggests that ethically-motivated CSR is more effective than economically-motivated CSR in building mutual trust and cooperation with stakeholders. Recent studies show that stakeholders such as consumers and employees can differentiate ethically-motivated CSR from economically-motivated CSR (Donia et al. 2017; Joo et al. 2019; McShane \& Cunningham 2012; Skilton \& Purdy 2017;). 
Building upon the research on the association between CSR and CFP and the studies on the difference between ethically- and economically-motivated CSR, we hypothesize that ethically-motivated CSR are associated with CFP as economically-motivated CSR does; in addition, the effect of ethically-motivated CSR engagement on CFP is more positive than that of economically-motivated CSR engagement, and so ethical CSR firms outperform economic CSR firms financially. Our hypothesis is formally stated as below.

H: The effect of ethically-motivated CSR on corporate financial performance is more positive than that of economically-motivated CSR.

\section{Research Design}

\subsection{Difference-in-differences Analysis}

Because ethically-motivated and economically-motivated CSR are differentiated based on motives which are difficult to assess for outsiders (McWilliams \& Siegel 2011), most of prior studies seeking to differentiate the two are conceptual or qualitative (Alhouti et al. 2016; Beckman et al. 2009; Joo et al. 2019; McShane \& Cunningham 2012). To empirically differentiate firms taking the two perspectives of CSR, we draw on the resource-based view and exploit the financial crisis surrounding 2008 as an external shock to firms' resource availability to perform a quasi-experiment.

Recall that the economic CSR firms conduct a cost-benefit analysis focusing on financial costs and gains to determine whether to participate in CSR programs. When the benefits from CSR are greater than the costs, they could engage in CSR in the same way as ethical CSR firms do, making it an empirical challenge to distinguish them. The resource-based view states that a surplus of resources provides the financial and personnel wherewithal necessary to engage in 
CSR programs (Aragón-Correa \& Sharma 2003; J. B. McGuire et al. 1988). During the financial crisis, many firms face resource constraints due to shrinking consumer demands and tightened bank lending (Campello, Graham, \& Harvey 2010; Duchin, Ozbas, \& Sensoy 2010; Ivasina \& Scharfstein 2010). As a result, the costs of CSR increase as firms face the trade-off between cutting resources devoted to CSR to deal with financial and personnel constraints and continuing CSR engagement with reduced resources available for the core business. Economic CSR firms thus are likely to hold off CSR engagement and retain limited resources for fundamental operations during the financial crisis (Aguilera-Caracuel, Guerrero-Villegas, Vidal-Salazar, \& Delgado-Márquez 2015). On the other hand, the financial crisis reveals moral and social problems that deserve prompt attention (e.g., Fassin \& Gosselin 2011). Ethical CSR firms should gear themselves up to address the issues. In this sense, the financial crisis offers a quasiexperimental setting to empirically distinguish ethical and economic CSR firms.

We classify the firms increasing CSR engagement during the financial crisis as ethical CSR firms; the others are classified as economic CSR firms. CSR engagement is operationalized as CSR performance rated by MSCI ESG (formerly KLD). MSCI ESG provides CSR ratings on the strength and the concern aspects from six dimensions, namely community, diversity, employee relations, environment, human right, and product quality. ${ }^{2}$ The dataset is widely used in prior studies on CSR (Deckop et al. 2006; Flammer 2015; Graves and Waddock 1994). We construct a composite CSR index by subtracting the sum of the number of concerns from the sum of the number of strengths (Kim et al. 2012; Mahoney \& Roberts 2007; Mahoney, Thorne, Cecil, \& LaGore 2013; Waddock \& Graves 1997; ).

\footnotetext{
${ }^{2}$ MSCI ESG provides CSR ratings on seven dimensions. We exclude the dimension of corporate governance because it is perceived as a distinct construct from CSR (Kim, Park, and Wier, 2015) and is mechanically associated with CFP (e.g., Core et al. 1999; Lefort and Urzua 2009).
} 
Each ethical CSR firm is then matched to an economic CSR firm in the same two-digit SIC industry that is the nearest neighbor firm with the lowest Mahalanobis distance ${ }^{3}$ across eight matching characteristics including size, sales, debt, cash holding, product market concentration, return on assets, return on equity, and CSR performance (i.e., composite CSR index). All matching variables are measured as the average of the two years prior to the financial crisis (i.e., 2006 and 2007) to ensure that the economic CSR firms are similar to the ethical CSR firms ex ante (Flammer 2015). Detailed variable definitions are provided in Appendix. All characteristics except for the composite CSR index are winsorized at the $1^{\text {st }}$ and $99^{\text {th }}$ percentiles.

\subsection{Empirical Model}

We perform a difference-in-differences analysis on the ethical and economic CSR firm sample with Model (1):

$$
\Delta C F P_{i}=\alpha+\beta * \text { ETHIC }_{i}+\gamma * \text { Controls }_{i}+\varepsilon_{i}
$$

where $\triangle C F P_{i}$ represents the change in one of the two CFP metrics examined, ROA and $R O E$, from the pre-crisis to the post-crisis period. Following prior research (e.g., Bouslah et al. 2018; Frankel \& Saravelos 2012; Lins, Servaes, \& Tamayo, 2017), we define the financial crisis is the period of 2008 and 2009, thus the pre-crisis period is 2006 and 2007, and the post-crisis period is 2010 and 2011. The pre-crisis ROA (ROE) is calculated as the mean ROA (ROE) in 2006 and 2007 and the post-crisis $R O A(R O E)$ is calculated as the mean ROA (ROE) in 2010 and 2011. ETHIC $_{i}$ is an indicator variable for the ethical CSR firms, which is coded as 1 if firms experience the increase in the composite CSR index during the financial crisis period, 0

\footnotetext{
${ }^{3}$ The Mahalanobis distance $\delta$ between treated firm I and candidate firm $j$ is given by $\delta=\left[\left(X_{i}-\right.\right.$ $\left.\left.X_{j}\right)^{\prime} \Sigma^{-1}\left(X_{i}-X_{j}\right)\right]^{1 / 2}$, where $X$ is a $(8 \times 1)$ vector containing the eight matching variables and $\Sigma$ is the $(8 \times 8)$ covariance matrix of the eight variables (Flammer, 2015).
} 
otherwise (treated as economic CSR firms). The difference in the change in CFP between the ethical and the economic CSR firms is reflected in the coefficient of $E T H I C_{i,} \beta$. A positive $\beta$ suggests that the effect of ethically-motivated CSR on CFP is more positive than that of economically-motivated CSR, providing support to our hypothesis. Controls $s_{i}$ represent the factors affecting CFP documented in prior literature (Flammer 2015; McWilliams \& Siegel 2000; Waddock \& Graves 1997) and are measured as the average in the pre-crisis period (Flammer 2015). We control for size computed as the natural logarithm of total assets (SIZE_PRE), the market-to-book ratio $\left(M B_{-} P R E\right)$ which is the ratio of the market value of equity to the book value of equity, cash holdings $\left(C A S C_{-} P R E\right)$ measured as cash and short-term investment scaled by total assets, the leverage ratio ( $\left.L E V \_P R E\right)$ computed as long-term debts scaled by total assets, product market concentration (HHI_PRE) measured by HerfindahlHirschman index, and pre-crisis $R O A_{-} P R E\left(R O E_{-} P R E\right)$. All continuous variables are winsorized at the $1^{\text {st }}$ and $99^{\text {th }}$ percentiles to minimize the impact of outliers and extreme values. Detailed variable definitions are provided in Appendix. We also control for industry-fixed effects based on the two-digit SIC industry classification. Standard errors are robust and adjusted for heteroskedasticity.

\subsection{Sample Description and Statistics}

We begin with 2,465 firms that exist in both MSCI ESG and Compustat databases in 2008 and 2009. We then remove financial institutions ${ }^{4}$ and the firms with missing data to reach a sample of 1,362 firms, 471 of which are identified as the ethical CSR firms that experience an increase in the composite CSR index during the financial crisis period. Applying the matching

\footnotetext{
${ }^{4}$ We exclude financial institutions because they were given extensive government support during the financial crisis (Lins et al., 2017).
} 
procedure described above, we are able to find matched economic CSR firms for 470 out of the 471 ethical CSR firms, leading to a final sample of 940 firms. Panel A of Table 1 reports the sample selection procedure. As shown in Figure 1, the composite CSR index of the ethical CSR firms increases steadily from the pre-crisis period to the post-crisis period, suggesting that the ethical CSR firms continue their CSR commitment during the financial crisis. In contrast, the composite CSR index of the economic CSR firms declines from the pre-crisis period to the crisis period which indicates that they hold off their CSR engagement during the financial crisis. Figure 1 also shows that the economic CSR firms increase their CSR efforts in the post-crisis period when the costs of CSR engagement are supposedly lowered.

[Insert Figure 1 about Here]

Panel B of Table 1 reports industry distribution of the ethical and the economic CSR firms. A large number of our sample firms operate in the manufacturing industry followed by the service and the transportation industry. Panel C of Table 1 compares the pre-crisis firm characteristics used in the matching procedure. The test of differences suggests that the ethical and the economic CSR firms are similar in all matching observables except for SIZE_PRE. However, the normalized difference in SIZE_PRE reported in the last column is less than 0.25 , suggesting that the difference in SIZE between the ethical and the economic CSR firms is not economically significant (Jayaraman \& Milbourn 2014). The statistics in Panel C of Table 1 confirm that economic CSR firms are very identical to ethical CSR firms ex ante.

[Insert Table 1 about Here]

Panel A of Table 2 presents descriptive statistics for the variables in Model (1). The mean (median) of $\triangle R O A$ is $-0.006(-0.002)$ and the mean (median) of $\triangle R O E$ is $-0.030(-0.003)$, suggesting that the sample firms experience decreased CFP on average. Panel B of Table 2 
provides the Pearson correlation coefficients. ETHIC is positively and significantly associated with $\triangle R O A$ (coefficient: $0.095, p$-value: 0.003 ) and $\triangle R O E$ (coefficient: $0.079, p$-value: 0.016 ), providing preliminary support to our prediction that ethically-motivated CSR is more positively associated with CFP than economically-motivated CSR.

[Insert Table 2 about Here]

\section{Main Results}

\subsection{Univariate Analysis}

We open our analyses with a univariate comparison of the change in CFP from the precrisis period to the post-crisis period for the ethical and the economic CSR firms. As illustrated in Panel A of Figure 2, ROA of both subsamples of firms decreases from the pre-crisis period to the crisis-period, suggesting that the ethical and economic CSR firms are both negatively affected by the financial crisis, which is critical for fulfilling the parallel assumption of the difference-in-differences analysis. However, $R O A$ of the ethical CSR firms increases from 4.97 percent in the pre-crisis period to 5.20 percent in the post-crisis period, but $R O A$ of the economic CSR firms decreases dramatically from 5.27 percent in the pre-crisis period to 3.80 percent in the post-crisis period. The change in $R O A$ from the pre-crisis period to the post-crisis period for the ethical CSR firms is 1.70 percentage point greater than that for the economic CSR firms ( $t$ statistic: -2.93; p-value: 0.003 ), or 34 percent of the pre-crisis mean $R O A$ of the ethical CSR firms. 
Panel B of Figure 2 shows a similar trend with $R O E$. Specifically, $R O E$ of the ethical CSR firms falls from 11.05 percent in the pre-crisis period to 1.79 percent during the financial crisis, but recovers to 11.08 percent in the post-crisis period. ROE of the economic CSR firms is 12.11 prior to the financial crisis and also decreases because of the financial crisis, but it only increases to 6.16 percent subsequent to the financial crisis, which is still 5.95 percentage point lower than its pre-crisis $R O E$. The difference in the pre-crisis and post-crisis $R O E$ between the ethical and the economic CSR firms are significantly different at the 5\% level ( $t$-statistic: -2.42 ; $p$-value: 0.016). Overall, the univariate comparison results are consistent with our prediction that ethically-motiavted CSR has a more positive impact on CFP than economically-motiavted CSR does.

[Insert Figure 2 about Here]

\subsection{Multivariate Analysis}

Table 3 presents the results of estimating Model (1). Column (1) shows that the coefficient of $E T H I C$ is 0.014 ( $t$-statistic: $2.72, p$-value: 0.007 ), which suggests that ethical CSR firms outperform economic CSR firms financially in terms of the change in $R O A$ from the precrisis period to the post-crisis period, providing support to our hypothesis. In terms of economic significance, the difference of 1.4 percentage point is equivalent to 28 percent of the mean $R O A$ of the ethical CSR firms in the pre-crisis period, which is economically meaningful. In the column (2), the coefficient of ETHIC is 0.048 ( $t$-statistic: $2.20, p$-value:0.028), which indicates that the ethical CSR firms improve ROE more than the economic CSR firms do by 4.8 percentage point, or 43 percent of the pre-crisis mean $R O E$ of the ethical firms. As for the control variables, we find larger firms enjoy greater improvement in $R O A(R O E)$ but firms with higher 
cash holding and higher $R O A(R O E)$ in the pre-crisis period have less increases in $R O A(R O E)$ from the pre-crisis period to the post-crisis period.

[Insert Table 3 about Here]

The economic CSR subsample includes both the firms decreasing their CSR efforts and those keeping their CSR efforts unchanged. The former firms are likely to be more economically-motivated than the latter on a continuum with ethically-motivated CSR and economically-motivated CSR as the two ends. To investigate the effect of the subtle difference on CFP, we include an additional indicator variable, SEMIETHIC, in Model (1) for the economic CSR firms with unvarying CSR commitment during the crisis period and re-estimate Model (1) on the ethical and economic CSR firm sample. The results (untabulated) show that the coefficient of SEMIETHIC is positive and statistically significant (coefficient: 0.082 ; $p$-value: 0.012 ) when CFP is measured by ROE. The coefficient of SEMIETHIC is also positive with ROA being the dependent variable but it is not statistically significant. Taken together, the analyses seem to suggest that the positive effect of CSR on CFP strengthens as firms move closer towards the ethical CSR end of the continuum.

Overall, the results are consistent with our prediction that ethically-motivated CSR is positively associated with CFP and that ethically-motivated CSR is more effective than economically-motivated CSR in enhancing CFP.

\section{Additional Analyses}

\subsection{Dimensional CSR Commitment and CFP}

The first set of additional analyses examines the effect of CSR commitment in each of the six dimensions on CFP. To perform the analyses, we create an ethical CSR firm sample and a 
matched economic CSR firm sample for each of the six dimensions of CSR following the same matching procedure as described in the main analyses. To ensure that the ethical and the economic CSR firms are similar in CSR commitment in the dimension examined ex ante, one of the matching variables, CSR INDEX_PRE, is substituted by the average of the dimensional CSR index in the pre-crisis period (CSR INDEX_DIM_PRE). The ethical CSR firms are the firms increasing the dimensional CSR commitment from the pre-crisis period to the crisis period while the others are classified as the economic CSR firms. We then estimate Model (1) for each of the six ethical and economic CSR samples.

Our analyses reveal that ethically-motivated CSR in the dimension of employee relations is most beneficial to CFP. As reported in the column (1) of Table 4, the coefficient of ETHIC_EMP is 0.022 (p-value: 0.001$)$, suggesting that the ethical CSR firms with increased efforts for employee relations during the financial crisis enjoy an increase in ROA that is 2.2 percentage point more than that of the economic CSR firms from the pre-crisis to the post-crisis period. The coefficient of ETHIC_EMP in the column (2) is also significantly positive when $R O E$ is the dependent variable (coefficient: $0.059, p$-value: 0.024$).$ In addition, the column (3) and (4) of Table 4 show that ETHIC_DIV is positively associated with $\triangle R O A$ and $\triangle R O E$ (coefficient: $0.050, p$-value: 0.053 ), though the coefficient is not statistically significant when $\triangle R O A$ is the dependent variable. The stronger effect of ethically-motivated CSR in diversity is also economically meaningful with a difference of 5.0 percentage point in $R O E$ improvement between the ethical and the economic CSR firms. MSCI ESG evaluates firms' diversity based on leadership, promotion policies, work-life balance, employment of women, minority, gay or lesbian, etc., many of which are relevant to employees. Taken together, our results are consistent with prior research documenting that employees are able to differentiate ethically- and 
economically-motivated CSR (Donia et al. 2017; McShane \& Cunningham 2012). The effect of ethically- and economically-motivated CSR is not significantly different in the other dimensions possibly because of small sample sizes.

[Insert Table 4 about Here]

\subsection{Alternative Measure of CSR Commitment}

The second set of additional analyses employs an alternative measure of CSR engagement. We aggregate CSR strengths and concerns to construct a composite CSR index in the main analyses. However, firms can promote CSR by either "doing good" or "avoiding bad" and the two may have distinct impact on CFP. Increasing CSR strengths has the effect of lighthouse that signal firms' commitment to "doing good" while decreasing CSR concerns is more self-evident and taken-for-granted (Lin-Hi Donia et al. 2017; Müller 2013; Zyglidopoulos et al. 2012). It is plausible that the two aspects of ethically-motivated CSR commitment have distinct impact on CFP and the effect of ethically-motivated CSR "doing good" is more pronounced. To investigate the possibility, we examine the effect of increasing the number of CSR strengths and decreasing the number of CSR concerns separately.

To examine the effect of CSR strengths, we measure CSR commitment with the sum of the number of CSR strengths in the six dimensions rated by MSCI ESG and then construct the ethical and economic CSR firms following the procedures described earlier for estimating Model (1). All matching variables are the same except for CSR INDEX_PRE which is replaced with the pre-crisis average of a CSR strength index calculated as the sum of the number of CSR strengths (CSR INDEX_STR_PRE). ETHIC in Model (1) is replaced with ETHIC_STR which is an indicator variable for the ethical CSR firms increasing the number of CSR strengths during the 
financial crisis. The results of the analyses are presented in Table 5. The coefficient of ETHIC_STR is 0.019 ( $t$-statistic: $3.50, p$-value: 0.000$)$ in the column (1) and $0.050(t$-statistic: 2.11, $p$-value: 0.035 ) in the column (2), which suggests that the ethical CSR firms increasing the number of CSR strengths enjoy an increase in $R O A(R O E)$ that is $1.90(5.00)$ percentage point more than that of the economic CSR firms. In untabulated analyses, we examine the effect of decreasing the number of CSR concerns, but the positive effect of ethically-motivated CSR "avoiding bad" on CFP is not significantly stronger than that of economically-motivated CSR "doing good", suggesting that the different effect of ethically- and economically-motivated CSR on CFP is primarily attributable to CSR "doing good".

[Insert Table 5 about Here]

We also examine the effect of increasing the number of CSR strengths in each of the six CSR dimensions on CFP. Table 6 reports the results. The significantly positive coefficient of ETHIC_STR_EMP (coefficient: 0.015, p-value: 0.026 ) means that ethically-motivated CSR increasing the number of strengths in the aspect of employee relations are associated with a greater improvement in $R O A$ than the economically-motivated CSR (coefficient: $0.015, p$-value: 0.026). However, ethically-motivated CSR increasing the number of strengths in employee relations does not result in a greater improvement in $R O E$. Neither do we find ethicallymotivated CSR increasing the number of CSR strengths in diversity are associated with a greater improvement in CFP. Ex post, we interpret the results as suggesting that limited CSR commitment in certain dimensions is less effective and it is harder to detect its positive impact on CFP given the restricted sample.

[Insert Table 6 about Here] 


\section{Conclusion}

This study investigates the effect of ethically- and economically-motivated CSR on CFP. We exploit the financial crisis surrounding 2008 as an external shock on firms' financial resource availability to empirically differentiate firms that engage in CSR for ethical and financial reasons and conduct difference-in-differences analyses to alleviate a potential endogeneity problem in the relation between CSR and CFP. Our analyses suggest that ethically-motivated CSR has more positive effect on CFP measured by both $R O A$ and $R O E$ than that of economically-motivated CSR. Our study extends prior research that conceptually or qualitatively suggests that ethicallymotivated CSR and economically-motivated CSR has different impact on CFP (Jones 1995; Beckman et al. 2009; Mazutis and Slawinski 2014). Further, we show that ethical CSR firms benefit most from CSR programs improving employee relations, and that increasing CSR strengths is more effective than decreasing CSR concerns.

The study contributes to the literature on the relation between CSR and CFP by empirically documenting that ethically-motivated CSR improves CFP more than economicallymotivated CSR does, thereby highlighting the real impact of ethically- and economicallymotivated CSR and establishing an important link between ethically-motivated CSR and CFP. Our study is also related to the research integrating the ethically- and economically-motivated CSR. The findings of the study confirm that ethically-motivated CSR and CFP are not mutually exclusive. 


\section{Reference}

Abbott, W. F., \& Monsen, R. J. (1979). On the measurement of corporate social responsibility: Self-reported disclosures as a method of measuring corporate social involvement. Academy of Management Journal, 22(3), 501-515.

Aguilera-Caracuel, J., Guerrero-Villegas, J., Vidal-Salazar, M. D., \& Delgado-Márquez, B. L. (2015). International cultural diversifcation and corporate social performance in multinational enterprises: The role of slack fnancial resources. Management International Review, 55(3), 323-353

Alexander, G. J., \& Buchholz, R. A. (1978). Corporate social responsibility and stock market performance. Academy of Management Journal, 21(3), 479-486.

Alhouti, S., Johnson, C. M., \& Holloway, B. B. (2016). Corporate social responsibility authenticity: Investigating its antecedents and outcomes. Journal of Business Research, 69(3), 1242-1249.

Aragón-Correa, J. A., \& Sharma, S. (2003). A contingent resource-based view of proactive corporate environmental strategy. Academy of Management Review, 28(1), 71-88.

Barney, J. (1991). Firm resources and sustained competitive advantage. Journal of Management, 17(1), 99-120.

Beckman, T., Colwell, A., \& Cunningham, P. H. (2009). The emergence of corporate social responsibility in Chile: The importance of authenticity and social networks. Journal of Business Ethics, 86(2), 191.

Bouslah, K., Kryzanowski, L., \& M'Zali, B. (2016). Social performance and firm risk: impact of the financial crisis. Journal of Business Ethics, 1-27.

Bragdon, J. H., \& Marlin, J. (1972). Is pollution profitable. Risk management, 19(4), 9-18. 
Campello, M., Graham, J.R., \& Harvey, C.R.( 2010). The real effects of financial constraints: evidence from afinancial crisis. Journal of Financial Economics, 97(3), 470-487.

Chatterji, A. K., Levine, D. I., \& Toffel, M. W. (2009). How well do social ratings actually measure corporate social responsibility? Journal of Economics \& Management Strategy, $18(1), 125-169$.

Chang, Y.K., Oh, W.Y., \& Messersmith, J. (2013). Translating corporate social performance into financial performance: Exploring the moderating role of high performance work practices. International Journal of Human Resource Management, 24 (19), 3738-3756.

Cho, C. H., Guidry, R. P., Hageman, A. M., \& Patten, D. M. (2012). Do actions speak louder than words? An empirical investigation of corporate environmental reputation. Accounting, Organizations and Society, 37(1), 14-25.

Christensen, D. M. (2015). Corporate accountability reporting and high-profile misconduct. The Accounting Review, 91(2), 377-399.

Christmann, P. (2000). Effects of "best practices" of environmental management on cost advantage: The role of complementary assets. Academy of Management Journal, 43(4), 663-680.

Chung, J., \& Cho, C. H. (2018). Current Trends within Social and Environmental Accounting Research: A Literature Review. Accounting Perspectives, 17(2), 207-239.

Cochran, P. L., \& Wood, R. A. (1984). Corporate social responsibility and financial performance. Academy of Management Journal, 27(1), 42-56.

Cornell, B., \& Shapiro, A. C. (1987). Corporate stakeholders and corporate finance. Financial Management, 16(1), 5-14. 
Deckop, J. R., Merriman, K. K., \& Gupta, S. (2006). The effects of CEO pay structure on corporate social performance. Journal of Management, 32(3), 329-342.

Dierynck, B., Landsman W. R., \& Renders A. (2012). Do managerial incentives drive cost behavior? Evidence about the role of the zero earnings benchmark for labor cost behavior in private Belgian firms. The Accounting Review, 87(4): 1219-1246.

Donaldson, T., \& Preston, L. E. (1995). The stakeholder theory of the corporation: Concepts, evidence, and implications. Academy of Management Review, 20(1), 65-91.

Donia, M. B., Ronen, S., Sirsly, C.-A. T., \& Bonaccio, S. (2017). CSR by any other name? The differential impact of substantive and symbolic CSR attributions on employee outcomes. Journal of Business Ethics, 157(2), 1-21.

Duchin, R., Ozbas. O., \& Sensoy. B. (2009). Costly External Finance, Corporate Investment, and the Subprime Mortgage Credit Crisis. Journal of Financial Economics, 97(3), 418-435.

Driver, M. (2006). Beyond the stalemate of economics versus ethics: Corporate social responsibility and the discourse of the organizational self. Journal of Business Ethics, $66(4), 337-356$.

Ellen, P. S., Webb, D. J., \& Mohr, L. A. (2006). Building corporate associations: Consumer attributions for corporate socially responsible programs. Journal of the Academy of Marketing Science, 34(2), 147-157.

Fassin, Y., \& Gosselin, D. (2011). The collapse of a European bank in the financial crisis: An analysis from stakeholder and ethical perspectives. Journal of Business Ethics, 102(2), $169-191$.

Flammer, C. (2015). Does corporate social responsibility lead to superior financial performance? A regression discontinuity approach. Management Science, 61(11), 2549-2568. 
Fogler, H. R., \& Nutt, F. (1975). A note on social responsibility and stock valuation. Academy of Management Journal, 18(1), 155-160.

Frankel, J., \& Saravelos, G. (2012). Can leading indicators assess country vulnerability? Evidence from the 2008-09 global financial crisis. Journal of International Economics, 87(2), 216-231.

Freeman, R. E. (1984). Strategic management: A stakeholder perspective. Englewood Cliffs, NJ: Prentice Hall.

Friedman, M. (1970, September 13, 1970). The Social Responsibility of Business is to Increase its Profits. New York Times Magazine, pp. 173-178.

Godfrey, P. C. (2005). The relationship between corporate philanthropy and shareholder wealth: A risk management perspective. Academy of Management Review, 30(4), 777-798.

Godfrey, P. C., Merrill, C. B., \& Hansen, J. M. (2009). The relationship between corporate social responsibility and shareholder value: An empirical test of the risk management hypothesis. Strategic Management Journal, 30(4), 425-445.

Gu, L. (2016). Product market competition, R\&D investment, and stock returns. Journal of Financial Economics, 119(2), 441-455.

Graves, S. B., \& Waddock, S. A. (1994). Institutional owners and corporate social performance. Academy of Management Journal, 37(4), 1034-1046.

Hill, C. W., \& Jones, T. M. (1992). Stakeholder-agency theory. Journal of Management Studies, 29(2), 131-154.

Hillman, A. J., \& Keim, G. D. (2001). Shareholder value, stakeholder management, and social issues: what's the bottom line? Strategic Management Journal, 22(2), 125-139. 
Hull, C. E., \& Rothenberg, S. (2008). Firm performance: The interactions of corporate social performance with innovation and industry differentiation. Strategic Management Journal, 29(7), 781-789.

Ingram, R. W. (1978). An investigation of the information content of (certain) social responsibility disclosures. Journal of Accounting Research, 16(2), 270-285.

Jayaraman, S., \& Milbourn, T. (2014). CEO equity incentives and financial misreporting: The role of auditor expertise. The Accounting Review, 90(1), 321-350.

Jones, T. M. (1995). Instrumental stakeholder theory: A synthesis of ethics and economics. Academy of Management Review, 20(2), 404-437.

Joo, S., Miller, E. G., \& Fink, J. S. (2019). Consumer evaluations of CSR authenticity:

Development and validation of a multidimensional CSR authenticity scale. Journal of Business Research, 98, 236-249.

Kim, Y., Park, M. S., \& Wier, B. (2012). Is earnings quality associated with corporate social responsibility? The Accounting Review, 87(3), 761-796.

Lin-Hi, N., \& Müller, K. (2013). The CSR bottom line: Preventing corporate social irresponsibility. Journal of Business Research, 66(10), 1928-1936.

Mahapatra, S. (1984). Investor reaction to a corporate social accounting. Journal of Business Finance \& Accounting, 11(1), 29-40.

Mahoney, L., \& Roberts, R. W. Corporate social performance, financial performance and institutional ownership in Canadian firms. In Accounting forum, 2007 (Vol. 31, pp. 233253, Vol. 3): Taylor \& Francis 
Mahoney, L. S., Thorne, L., Cecil, L., \& LaGore, W. (2013). A research note on standalone corporate social responsibility reports: Signaling or greenwashing? Critical perspectives on Accounting, 24(4-5), 350-359.

Manchiraju, H., \& Rajgopal, S. (2017). Does corporate social responsibility (CSR) create shareholder value? Evidence from the Indian Companies Act 2013. Journal of Accounting Research, 55(5), 1257-1300.

Mazutis, D. D., \& Slawinski, N. (2015). Reconnecting business and society: Perceptions of authenticity in corporate social responsibility. Journal of Business Ethics, 131(1), 137150.

McGuire, J. B., Sundgren, A., \& Schneeweis, T. (1988). Corporate social responsibility and firm financial performance. Academy of Management Journal, 31(4), 854-872.

McGuire, J. W. (1963). Business and Society. New York: McGraw-Hill.

McShane, L., \& Cunningham, P. (2012). To thine own self be true? Employees' judgments of the authenticity of their organization's corporate social responsibility program. Journal of Business Ethics, 108(1), 81-100.

McWilliams, A., \& Siegel, D. (2000). Corporate social responsibility and financial performance: correlation or misspecification? Strategic Management Journal, 21(5), 603-609.

McWilliams, A., \& Siegel, D. (2001). Corporate social responsibility: A theory of the firm perspective. Academy of Management Review, 26(1), 117-127.

McWilliams, A., \& Siegel, D. S. (2011). Creating and capturing value: Strategic corporate social responsibility, resource-based theory, and sustainable competitive advantage. Journal of Management, 37(5), 1480-1495.

Milton, F. (1962). Capitalism and freedom. Chicago: University of Chicago Press. 
Moskowitz, M. (1972). Choosing socially responsible stocks. Business and Society Review, 1(1), $71-75$.

Orlitzky, M., Schmidt, F. L., \& Rynes, S. L. (2003). Corporate social and financial performance: A meta-analysis. Organization Studies, 24(3), 403-441.

Porter, M. E., \& Kramer, M. R. (2006). The link between competitive advantage and corporate social responsibility. Harvard Business Review, 84(12), 78-92.

Rodrigue, M., Magnan, M., \& Cho, C. H. (2013). Is environmental governance substantive or symbolic? An empirical investigation. Journal of Business Ethics, 114(1), 107-129.

Russo, M. V., \& Fouts, P. A. (1997). A resource-based perspective on corporate environmental performance and profitability. Academy of Management Journal, 40(3), 534-559.

Schneider, A. (2015). Reflexivity in sustainability accounting and management: Transcending the economic focus of corporate sustainability. Journal of Business Ethics, 127(3), 525536.

Shane, P. B., \& Spicer, B. H. (1983). Market response to environmental information produced outside the firm. The Accounting Review, 58(3), 521.

Skilton, P. F., \& Purdy, J. M. (2017). Authenticity, power, and pluralism: A Framework for understanding stakeholder evaluations of corporate social responsibility activities. Business Ethics Quarterly, 27(1), 99-123.

Spicer, B. H. (1978). Investors, corporate social performance and information disclosure: An empirical study. The Accounting Review, 53(1), 94-111.

Sturdivant, F. D., \& Ginter, J. L. (1977). Corporate social responsiveness: Management attitudes and economic performance. California Management Review, 19(3), 30-39. 
Waddock, S. A., \& Graves, S. B. (1997). The corporate social performance-financial performance link. Strategic Management Journal, 18(4), 303-319.

Wang, Y.J. \& Berens, G. (2015). The Impact of Four Types of Corporate Social Performance on Reputation and Financial Performance. Journal of Business Ethics, 131(2), 337-359.

Wang, Q., Dou, J., \& Jia, S. (2016). A meta-analytic review of corporate social responsibility and corporate financial performance: The moderating effect of contextual factors. Business \& Society, 55(8), 1083-1121.

Windsor, D. (2001). The future of corporate social responsibility. International Journal of Organizational Analysis, 9(3), 225-256.

Windsor, D. (2006). Corporate social responsibility: Three key approaches. Journal of Management Studies, 43(1), 93-114.

Zyglidopoulos, S. C., Georgiadis, A. P., Carroll, C. E., \& Siegel, D. S. (2012). Does media attention drive corporate social responsibility? Journal of Business Research, 65(11), $1622-1627$. 


\section{Appendix: Definitions of Variables}

\begin{tabular}{|c|c|}
\hline Variables & Definitions \\
\hline \multicolumn{2}{|l|}{ Matching variables } \\
\hline CSR INDEX_PRE & $\begin{array}{l}\text { Average of the composite CSR index in the pre-crisis period (2006 } \\
\text { and 2007). The composite CSR index is the sum of CSR strengths } \\
\text { minus the sum of CSR concerns; both CSR strengths and concerns } \\
\text { include six dimensions that are community, diversity, employee } \\
\text { relations, environment, human right, and product quality. }\end{array}$ \\
\hline$R O A \_P R E$ & $\begin{array}{l}\text { Average of ROA in the pre-crisis period ( } 2006 \text { and } 2007) ; R O A \text { in } \\
\text { year } t \text { is computed as net income (I) in year } t \text { divided by total } \\
\text { assets ( } \underline{\mathrm{AT}}) \text { at the end of year } t \text {. }\end{array}$ \\
\hline$R O E \_P R E$ & $\begin{array}{l}\text { Average of ROE in the pre-crisis period ( } 2006 \text { and } 2007) ; R O E \text { in } \\
\text { year } t \text { is computed as net income (NI) in year } t \text { divided by book } \\
\text { value of equity ( } \underline{\mathrm{CEQ}}) \text { at the end of year. }\end{array}$ \\
\hline \multirow[t]{2}{*}{ HHI_PRE } & $\begin{array}{l}\text { Market competition measured by average of Herfindahl-Hirschman } \\
\text { index in the pre-crisis period ( } 2006 \text { and 2007). Herfindahl- }\end{array}$ \\
\hline & $\begin{array}{l}\text { Hirschman index in industry } j \text { in year } t \text { is calculated by squaring the } \\
\text { market share for each firm and then summing the squares; market } \\
\text { share of firm } i \text { is calculated by dividing the firm's sales (SALE) by } \\
\text { the total sales of the industry. Industry is defined based on two-digit } \\
\text { SIC classifications (Gu, 2016). }\end{array}$ \\
\hline SIZE_PRE & $\begin{array}{l}\text { Average of the natural logarithm of total assets }(\underline{\mathrm{AT}}) \text { in the pre-crisis } \\
\text { period (2006 and 2007). }\end{array}$ \\
\hline LNCASH_PRE & $\begin{array}{l}\text { Average of the natural logarithm of cash and short-term investments } \\
\text { (CHE) in the pre-crisis period ( } 2006 \text { and 2007). }\end{array}$ \\
\hline DEBT_PRE & $\begin{array}{l}\text { Average of the natural logarithm of the long-term debt (DLTT) in } \\
\text { the pre-crisis period ( } 2006 \text { and 2007). }\end{array}$ \\
\hline SALE_PRE & $\begin{array}{l}\text { The average of the natural logarithm of sales (SALE) in the pre- } \\
\text { crisis period ( } 2006 \text { and 2007). }\end{array}$ \\
\hline CSR INDEX_STR_PRE & $\begin{array}{l}\text { Average of the composite CSR strength index in the pre-crisis period } \\
(2006 \text { and 2007). The composite CSR strength index is the sum of } \\
\text { CSR strengths which include six dimensions that are community, } \\
\text { diversity, employee relations, environment, human right, and } \\
\text { product quality. }\end{array}$ \\
\hline CSR & Average of the composite CSR dimensional index in the pre-crisis \\
\hline INDEX_DIM_PRE & $\begin{array}{l}\text { period (2006 and 2007). The composite CSR dimensional index is } \\
\text { the sum of CSR strengths minus the sum of CSR concerns in each of } \\
\text { the six dimensions that are community, diversity, employee } \\
\text { relations, environment, human right, and product quality. }\end{array}$ \\
\hline \multicolumn{2}{|c|}{ Variables in the regression model } \\
\hline$\triangle R O A$ & $\begin{array}{l}\text { Change in average return on assets from the pre-crisis period ( } 2006 \\
\text { and 2007) to the post-crisis period ( } 2010 \text { and } 2011) \text {; return on assets } \\
\text { in year } t \text { is calculated as net income ( } \underline{\mathrm{NI}} \text { ) in year } t \text { divided by total } \\
\text { assets ( } \underline{\mathrm{AT}}) \text { at the end of year } t \text {. }\end{array}$ \\
\hline
\end{tabular}

(continued on next page) 


\section{Appendix (continued)}

\begin{tabular}{|c|c|}
\hline Variables & Definitions \\
\hline$\triangle R O E$ & $\begin{array}{l}\text { Change in average return on equity from the pre-crisis period ( } 2006 \\
\text { and } 2007) \text { to the post-crisis period }(2010 \text { and } 2011) \text {; return on equity } \\
\text { in year } t \text { is calculated as net income }(\underline{\mathrm{NI}}) \text { in year } t \text { divided by book } \\
\text { value of equity (CEQ) at the end of year } t \text {. }\end{array}$ \\
\hline ETHIC & $\begin{array}{l}\text { An indicator variable that equals one for firms with increased overall } \\
\text { CSR index from the pre-crisis period ( } 2006 \text { and 2007) to the crisis } \\
\text { period ( } 2008 \text { and 2009), and zero otherwise. }\end{array}$ \\
\hline ETHIC_EMP & $\begin{array}{l}\text { An indicator variable that equals one for firms with increased CSR } \\
\text { index in employee relations from the pre-crisis period ( } 2006 \text { and } \\
2007) \text { to the crisis period ( } 2008 \text { and } 2009) \text {, and zero otherwise. }\end{array}$ \\
\hline ETHIC_DIV & $\begin{array}{l}\text { An indicator variable that equals one for firms with increased CSR } \\
\text { index in diversity from the pre-crisis period ( } 2006 \text { and 2007) to the } \\
\text { crisis period ( } 2008 \text { and 2009), and zero otherwise. }\end{array}$ \\
\hline ETHIC_STR & $\begin{array}{l}\text { An indicator variable that equals one for firms increasing the number } \\
\text { of CSR strengths from the pre-crisis period ( } 2006 \text { and 2007) to the } \\
\text { crisis period ( } 2008 \text { and 2009), and zero otherwise. }\end{array}$ \\
\hline ETHIC_STR_EMP & $\begin{array}{l}\text { An indicator variable that equals one for firms increasing the number } \\
\text { of CSR strengths in employee relations from the pre-crisis period } \\
\text { ( } 2006 \text { and 2007) to the crisis period ( } 2008 \text { and 2009), and zero } \\
\text { otherwise. }\end{array}$ \\
\hline ETHIC_STR_DIV & $\begin{array}{l}\text { An indicator variable that equals one for firms increasing the number } \\
\text { of CSR strengths in diversity from the pre-crisis period ( } 2006 \text { and } \\
2007) \text { to the crisis period ( } 2008 \text { and 2009), and zero otherwise. }\end{array}$ \\
\hline$H H I \_P R E$ & $\begin{array}{l}\text { Average of Herfindahl-Hirschman index in the pre-crisis period } \\
(2006 \text { and } 2007) \text {. Herfindahl-Hirschman index in industry } j \text { in year } t \\
\text { is calculated by squaring the market share for each firm and then } \\
\text { summing the squares ( } \mathrm{Gu}, 2016) \text {. }\end{array}$ \\
\hline SIZE_PRE & $\begin{array}{l}\text { Average of the natural logarithm of total assets }(\underline{\mathrm{AT}}) \text { in the pre-crisis } \\
\text { period }(2006 \text { and } 2007) \text {. }\end{array}$ \\
\hline$M B \_P R E$ & $\begin{array}{l}\text { Average of the ratio of the market value of equity }\left(\underline{\mathrm{PRCC}} \mathrm{F}^{*} \mathrm{CSHO}\right) \\
\text { to the book value of equity }(\underline{\mathrm{CEQ}}) \text { in pre-crisis period }(2006 \text { and } \\
2007) \text {. }\end{array}$ \\
\hline$L E V \_P R E$ & $\begin{array}{l}\text { Average of the ratio of long-term debt (DLTT) to total assets ( } \underline{\text { AT) }} \text { in } \\
\text { the pre-crisis period ( } 2006 \text { and } 2007) \text {. }\end{array}$ \\
\hline CASH_PRE & $\begin{array}{l}\text { Average of cash and short-term investments }(\underline{\mathrm{CHE}}) \text { scaled by total } \\
\text { assets }(\underline{\mathrm{AT}}) \text { in the pre-crisis period }(2006 \text { and } 2007) \text {. }\end{array}$ \\
\hline$R O A \_P R E$ & $\begin{array}{l}\text { Average of ROA in the pre-crisis period ( } 2006 \text { and } 2007) ; R O A \text { in } \\
\text { year } t \text { is computed as net income }(\underline{\mathrm{NI}}) \text { in year } t \text { divided by total } \\
\text { assets }(\underline{\mathrm{AT}}) \text { at the end of year } t .\end{array}$ \\
\hline$R O E \_P R E$ & $\begin{array}{l}\text { Average of ROE in the pre-crisis period ( } 2006 \text { and } 2007) ; R O E \text { in } \\
\text { year } t \text { is computed as net income ( } \underline{\mathrm{NI}}) \text { in year } t \text { divided by book } \\
\text { value of equity ( } \underline{\mathrm{CEQ}}) \text { at the end of year } t \text {. }\end{array}$ \\
\hline
\end{tabular}




\section{Figure 1 Composite CSR Index of the Ethical and the Economic CSR Firms}

\section{CSR Composite Index}

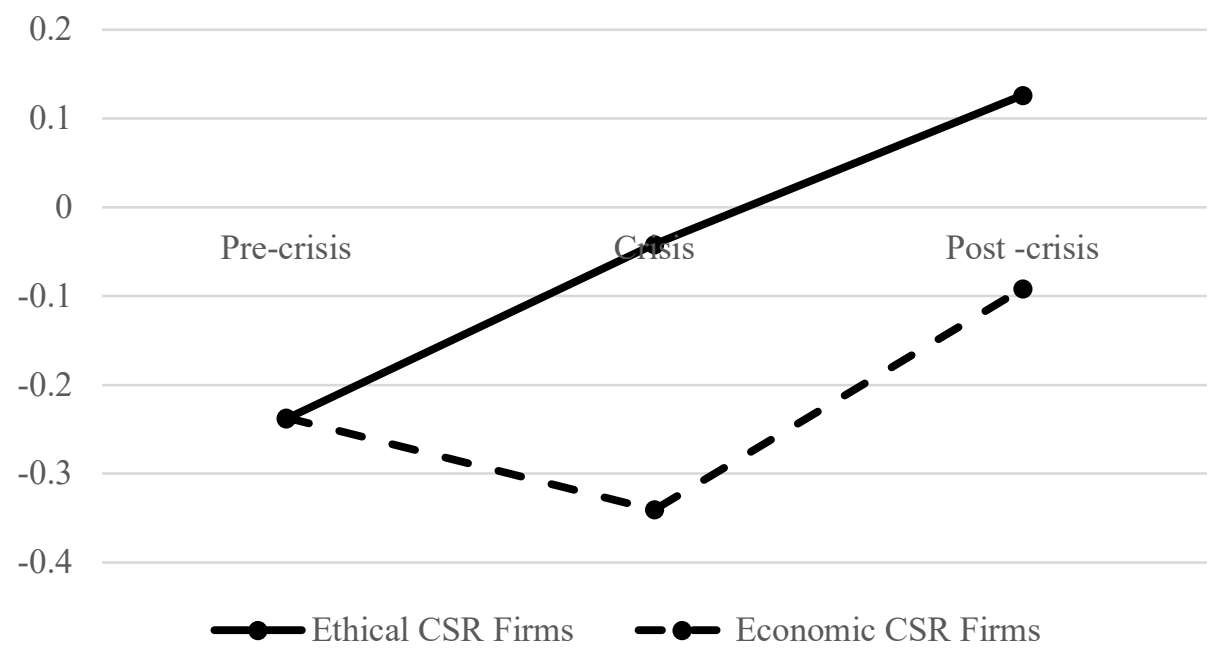

Figure 1 plots the composite CSR index of the ethical and the economic CSR firms surrounding the financial crisis. The pre-crisis period refers to the year 2006 and 2007; the crisis period includes the year 2008 and 2009; the postcrisis period refers to the year 2010 and 2011. The composite CSR index is the sum of the number of CSR strengths minus the sum of the number of CSR concerns in community, diversity, employee relations, environment, human right, and product quality rated by MSCI ESG. 
Figure $2 R O A$ and $R O E$ of the Ethical and the Economic CSR Firms

Panel A: $R O A$ of the ethical and the economic CSR firms surrounding the financial crisis

\section{$R O A$}

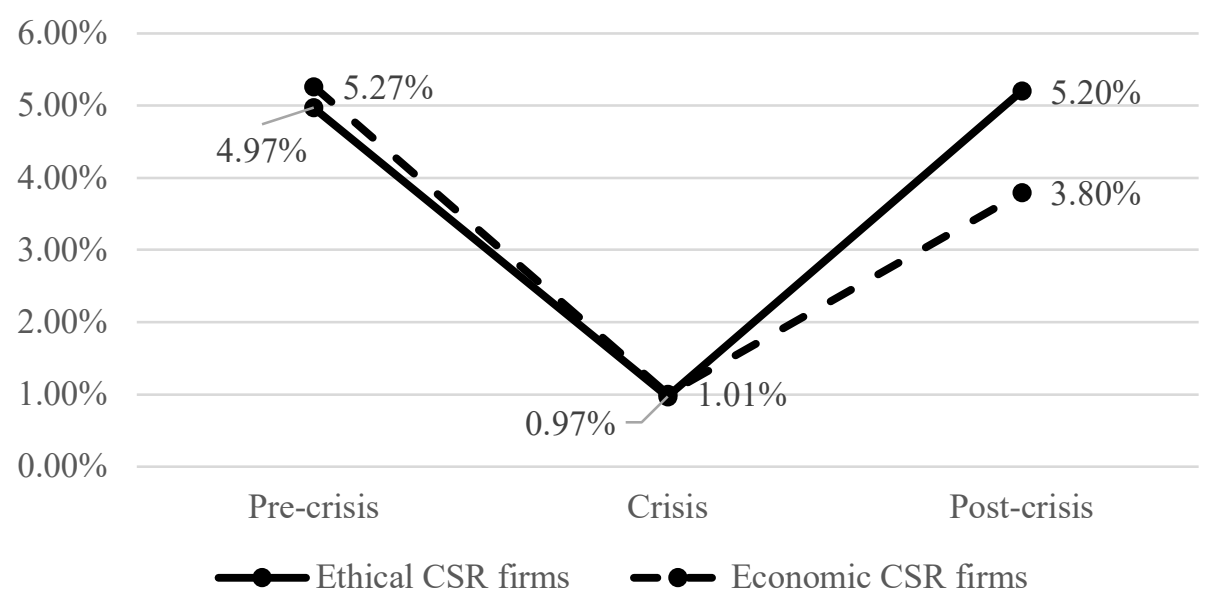

Panel B: $R O E$ of the ethical and the economic CSR firms surrounding the financial crisis

\section{ROE}

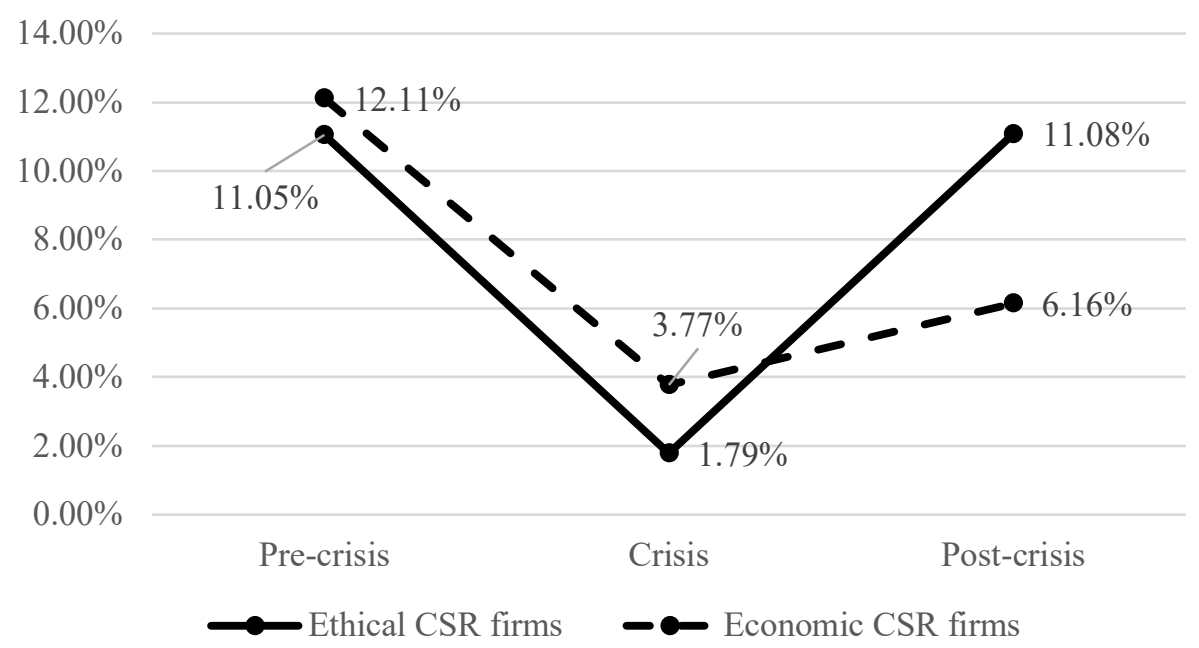

Figure 2 plots $R O A$ of the ethical and the economic CSR firms surrounding the financial crisis in Panel $\mathrm{A}$ and $R O E$ of the ethical and the economic CSR firms surrounding the financial crisis in Panel B. The pre-crisis period refers to the year 2006 and 2007; the crisis period includes the year 2008 and 2009; the post-crisis period refers to the year 2010 and 2011. The composite CSR index the sum of the number of CSR strengths minus the sum of the number of CSR concerns in community, diversity, employee relations, environment, human right, and product quality rated by MSCI ESG. ROA (ROE) in the pre-crisis period is the mean ROA (ROE) in the year 2006 and 2007; ROA (ROE) in the crisis period is the mean ROA (ROE) in the year 2008 and 2009; ROA (ROE) in the post-crisis period is the mean $R O A(R O E)$ in the year 2010 and 2011. ROA in year $t$ is net income in year $t$ divided by total assets at the end of year $t$. ROE in year $t$ is calculated as net income in year $t$ divided by book value of equity at the end of year $t$. 
Table 1 Sample Composition and Descriptive Statistics

Panel A: Composition of the Ethical CSR Sample

\begin{tabular}{|c|c|}
\hline & Observations \\
\hline Firms with records in both MSCI ESG and Compustat in 2008 & 2,465 \\
\hline Less: financial institutions (SIC codes between 6000 and 6999) & $(555)$ \\
\hline Less: firms with missing financial data or CSR data & $(548)$ \\
\hline Total & 1,362 \\
\hline Ethical CSR firms & 471 \\
\hline \multicolumn{2}{|l|}{ Matching Outcomes } \\
\hline Ethical CSR firms & 470 \\
\hline Economic CSR firms & 470 \\
\hline Total of final sample & 940 \\
\hline
\end{tabular}

\section{Panel B: Industry Distribution of Ethical CSR sample and the Economic CSR Sample}

\begin{tabular}{lccr}
\multicolumn{1}{c}{ Industry } & Ethical CSR firms & $\begin{array}{c}\text { Economic CSR } \\
\text { firms }\end{array}$ & Percent \\
\hline Agriculture, Forestry, \& Fishing & 2 & 2 & 0.43 \\
Mining & 30 & 30 & 6.38 \\
Construction & 5 & 5 & 1.06 \\
Manufacturing & 233 & 233 & 49.57 \\
Transportation \& Public Utilities & 64 & 64 & 13.62 \\
Wholesale Trade & 18 & 18 & 3.83 \\
Retail Trade & 43 & 43 & 9.15 \\
Services & 73 & 73 & 15.53 \\
Others & 2 & 2 & 0.43 \\
\hline Total & 470 & 470 & 100.00 \\
\hline
\end{tabular}

Panel C: Pre-crisis Characteristics of the Ethical and the Economic CSR Sample

\begin{tabular}{|c|c|c|c|c|c|}
\hline \multirow[b]{2}{*}{ Matching Variables } & \multirow[b]{2}{*}{$\mathrm{N}$} & \multicolumn{2}{|c|}{ Mean } & \multirow{2}{*}{$\begin{array}{c}\text { Test of Difference } \\
\text { ( } p \text {-value })\end{array}$} & \multirow{2}{*}{$\begin{array}{l}\text { Normalized } \\
\text { Difference }\end{array}$} \\
\hline & & Ethical & Economic & & \\
\hline CSR INDEX_PRE & 470 & -0.238 & -0.237 & 0.974 & -0.002 \\
\hline$R O A_{-} P R E$ & 470 & 0.050 & 0.053 & 0.597 & -0.035 \\
\hline$R O E_{-} P R E$ & 470 & 0.111 & 0.121 & 0.478 & -0.046 \\
\hline$H H I \_P R E$ & 470 & 0.069 & 0.069 & 1.000 & 0.000 \\
\hline$S I Z E \_P R E$ & 470 & 7.632 & 7.461 & 0.088 & 0.111 \\
\hline CASH_PRE & 470 & 5.012 & 4.887 & 0.228 & 0.079 \\
\hline$D E B T_{\_} P R E$ & 470 & 4.991 & 4.873 & 0.532 & 0.041 \\
\hline SALE_PRE & 470 & 7.412 & 7.265 & 0.173 & 0.089 \\
\hline
\end{tabular}

This table reports the sample selection process in Panel A, the industry distribution of the ethical and the economic CSR firms in Panel B, and a comparison of the pre-crisis characteristics of the ethical and the economic CSR firms in Panel C. Industries are defined based on two-digit SIC industries. 


\section{Table 2 Descriptive Statistics}

Panel A: Descriptive Statistics of Main Regression Variables

\begin{tabular}{lrrrrrr}
\hline Variable & $\mathrm{N}$ & Mean & STD & $\mathrm{p} 25$ & Median & $\mathrm{p} 75$ \\
\hline$\triangle R O A$ & 940 & -0.006 & 0.089 & -0.034 & -0.002 & 0.020 \\
$\triangle R O E$ & 940 & -0.030 & 0.380 & -0.080 & -0.003 & 0.047 \\
ETHIC & 940 & 0.500 & 0.500 & 0.000 & 0.500 & 1.000 \\
$H H I P R E$ & 940 & 0.069 & 0.065 & 0.032 & 0.047 & 0.087 \\
SIZE_PRE & 940 & 7.547 & 1.534 & 6.382 & 7.427 & 8.438 \\
$M B \_P R E$ & 940 & 3.181 & 2.822 & 1.731 & 2.505 & 3.764 \\
$L E V \_P R E$ & 940 & 0.191 & 0.166 & 0.039 & 0.175 & 0.279 \\
$C A S \bar{H} P R E$ & 940 & 0.161 & 0.184 & 0.029 & 0.083 & 0.227 \\
ROA_PRE & 940 & 0.051 & 0.084 & 0.028 & 0.057 & 0.092 \\
ROE_PRE & 940 & 0.116 & 0.229 & 0.065 & 0.124 & 0.187 \\
\hline
\end{tabular}

Panel B: Pearson Correlation Coefficients

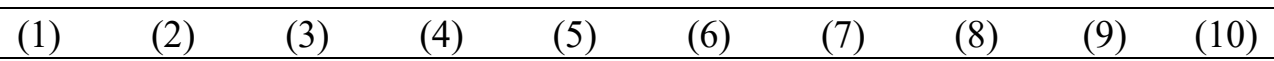

\begin{tabular}{|c|c|c|c|c|c|c|c|c|c|}
\hline (1) $\triangle R O A$ & & & & & & & & & \\
\hline (2) $\triangle R O E$ & 0.470 & & & & & & & & \\
\hline (3) ETHIC & 0.095 & 0.079 & & & & & & & \\
\hline (4) HHI_PRE & -0.061 & -0.027 & 0.000 & & & & & & \\
\hline (5) SIZE_PRE & 0.048 & -0.010 & 0.056 & 0.022 & & & & & \\
\hline (6) $M B \_P R E$ & -0.019 & -0.075 & 0.061 & -0.040 & -0.063 & & & & \\
\hline (7) $L E V \_P R E$ & 0.136 & -0.004 & 0.037 & 0.087 & 0.277 & -0.061 & & & \\
\hline (8) $C A S H \_P R E$ & -0.014 & 0.001 & 0.000 & -0.154 & -0.474 & 0.195 & -0.446 & & \\
\hline (9) ROA_PRE & $-\mathbf{0 . 4 5 7}$ & -0.190 & -0.017 & 0.062 & 0.135 & 0.171 & -0.148 & -0.213 & \\
\hline (10) ROE_PRE & -0.267 & -0.438 & -0.023 & 0.037 & 0.214 & 0.261 & -0.029 & -0.199 & 0.598 \\
\hline
\end{tabular}

This table reports the descriptive statistics of main regression variables in Panel A and Pearson correlation coefficients in Panel B. Correlation coefficients in bold are statistically significant at a significance level of $\mathrm{p}<0.10$. 
Table 3 The Impact of Ethical CSR on Firm Financial Performance

\begin{tabular}{|c|c|c|c|}
\hline & Dependent Variable & $\begin{array}{c}(1) \\
\Delta R O A \\
\end{array}$ & $\begin{array}{c}(2) \\
\Delta R O E\end{array}$ \\
\hline ETHIC & & $\begin{array}{l}0.014^{* * *} \\
(0.005)\end{array}$ & $\begin{array}{c}0.048^{* *} \\
(0.022)\end{array}$ \\
\hline$H H I$ & & $\begin{array}{c}1.169 \\
(0.716)\end{array}$ & $\begin{array}{c}1.587 \\
(1.808)\end{array}$ \\
\hline$S I Z E \_P R E$ & & $\begin{array}{l}0.005^{* * *} \\
(0.002)\end{array}$ & $\begin{array}{c}0.023^{* * * *} \\
(0.008)\end{array}$ \\
\hline$M B \_P R E$ & & $\begin{array}{c}0.002^{*} \\
(0.001)\end{array}$ & $\begin{array}{c}0.006 \\
(0.007)\end{array}$ \\
\hline$L E V \_P R E$ & & $\begin{array}{c}0.021 \\
(0.021)\end{array}$ & $\begin{array}{l}-0.179 \\
(0.136)\end{array}$ \\
\hline CASH_PRE & & $\begin{array}{l}-0.068^{* *} \\
(0.032)\end{array}$ & $\begin{array}{l}-0.274^{* *} \\
(0.117)\end{array}$ \\
\hline$R O A \_P R E$ & & $\begin{array}{l}-0.532^{* * *} \\
(0.081)\end{array}$ & \\
\hline$R O E \_P R E$ & & & $\begin{array}{l}-0.801^{\text {*** }} \\
(0.081)\end{array}$ \\
\hline INTERCEPT & & $\begin{array}{l}-0.282 \\
(0.174)\end{array}$ & $\begin{array}{l}-0.417 \\
(0.455)\end{array}$ \\
\hline Industry fixed effects & & Included & Included \\
\hline $\begin{array}{l}\text { Observations } \\
\text { R-squared }\end{array}$ & & $\begin{array}{c}940 \\
0.311\end{array}$ & $\begin{array}{c}940 \\
0.297\end{array}$ \\
\hline
\end{tabular}

This table reports the regression results on the impact of ethical CSR on CFP compared with economic CSR. The sample comprises 470 observations for firms with increased CSR composite index from the pre-crisis period (2006 and 2007) to the crisis period (2008 and 2009) and 470 observations for firms with unchanged or decreased composite CSR index from the pre-crisis period to the crisis period. The dependent variable in column (1) is the change in $R O A$ from the pre-crisis period (2006 and 2007) to the post-crisis period (2010 and 2011). The dependent variable in column (2) is the change in $R O E$ from the pre-crisis period to the post-crisis period. Detailed variable definitions are in Appendix. Standard errors, displayed in parentheses below coefficient estimates, are adjusted for heteroscedasticity. ${ }^{* * *}\left({ }^{* *}\right)\left({ }^{*}\right)$ indicates significance at the $1 \%(5 \%)(10 \%)$ level, using two-tailed tests. 
Table 4 The Impact of Ethical CSR in Employee Relation and Diversity on Firm Financial Performance

\begin{tabular}{lcccc}
\hline & $(1)$ & $(2)$ & $(3)$ & $(4)$ \\
Dependent Variable & $\Delta R O A$ & $\Delta R O E$ & $\Delta R O A$ & $\Delta R O E$ \\
\hline ETHIC_EMP & $0.022^{* * *}$ & $0.059^{* *}$ & & \\
& $(0.006)$ & $(0.026)$ & & \\
ETHIC_DIV & & & 0.005 & $0.050^{*}$ \\
& & & $(0.007)$ & $(0.026)$ \\
HHI_PRE & -0.204 & -2.946 & $1.940^{* * *}$ & 3.257 \\
& $(1.236)$ & $(2.290)$ & $(0.646)$ & $(2.188)$ \\
SIZE_PRE & $0.006^{* *}$ & $0.025^{* *}$ & $0.005^{*}$ & $0.034^{* * *}$ \\
& $(0.002)$ & $(0.011)$ & $(0.003)$ & $(0.010)$ \\
MB_PRE & 0.001 & 0.001 & 0.002 & $0.027^{* * *}$ \\
& $(0.002)$ & $(0.008)$ & $(0.002)$ & $(0.006)$ \\
LEV_PRE & 0.005 & -0.154 & 0.025 & -0.138 \\
& $(0.025)$ & $(0.149)$ & $(0.027)$ & $(0.160)$ \\
CASH_PRE & -0.051 & $-0.289^{* * *}$ & -0.038 & -0.087 \\
ROA_PRE & $(0.046)$ & $(0.134)$ & $(0.039)$ & $(0.124)$ \\
& $-0.513^{* * * *}$ & & $-0.681^{* * *}$ & \\
ROE_PRE & $(0.102)$ & & $(0.106)$ & $-0.890^{* * *}$ \\
& & $-0.750^{* * *}$ & & $(0.075)$ \\
INTERCEPT & & $(0.111)$ & & $-1.005^{*}$ \\
& 0.028 & 0.613 & $-0.464^{* * *}$ & $(0.563)$ \\
Industry fixed effects & Included & Included & Included & Included \\
Observations & & & & \\
R-squared & 592 & 592 & 482 & 482 \\
& 0.318 & 0.314 & 0.440 & 0.454 \\
\hline
\end{tabular}

This table reports the regression results on the impact of ethical CSR in employee relations on CFP in column (1) and (2) and the impact of ethical CSR in diversity on CFP in column (3) and (4). The employee relation sample comprises 296 observations for firms with increased composite CSR index in employee relation from the pre-crisis period (2006 and 2007) to the crisis period (2008 and 2009) and 296 observations for firms with unchanged or decreased composite CSR index in employee relation from the pre-crisis period to the crisis period. The diversity sample comprises 241 observations for firms with increased composite CSR index in diversity from the pre-crisis period to the crisis period and 241 observations for firms with unchanged or decreased composite CSR index in diversity from the pre-crisis period to the crisis period. The dependent variable in column (1) and (3) is the change in $R O A$ from the pre-crisis period (2006 and 2007) to the post-crisis period (2010 and 2011). The dependent variable in column (2) and (4) is the change in $R O E$ from the pre-crisis period to the post-crisis period. Detailed variable definitions are in Appendix. Standard errors, displayed in parentheses below coefficient estimates, are adjusted for heteroscedasticity. ${ }^{* * *}\left(^{* *}\right)\left({ }^{*}\right)$ indicates significance at the $1 \%(5 \%)(10 \%)$ level, using two-tailed tests. 
Table 5 The Impact of Ethical CSR on Firm Financial Performance-Alternative Sample

\begin{tabular}{|c|c|c|c|}
\hline & Dependent Variable & $\begin{array}{c}(1) \\
\triangle R O A \\
\end{array}$ & $\begin{array}{c}(2) \\
\Delta R O E \\
\end{array}$ \\
\hline ETHIC_STR & & $\begin{array}{l}0.019^{* * *} \\
(0.005)\end{array}$ & $\begin{array}{c}0.050^{* *} \\
(0.024)\end{array}$ \\
\hline HHI_PRE & & $\begin{array}{c}0.028 \\
(0.585)\end{array}$ & $\begin{array}{l}-1.324 \\
(2.749)\end{array}$ \\
\hline SIZE_PRE & & $\begin{array}{c}0.003 \\
(0.002)\end{array}$ & $\begin{array}{c}0.021^{* *} \\
(0.009)\end{array}$ \\
\hline$M B \_P R E$ & & $\begin{array}{c}0.003^{* *} \\
(0.001)\end{array}$ & $\begin{array}{c}0.004 \\
(0.009)\end{array}$ \\
\hline$L E V \_P R E$ & & $\begin{array}{c}0.012 \\
(0.025)\end{array}$ & $\begin{array}{l}-0.282^{* *} \\
(0.140)\end{array}$ \\
\hline CASH_PRE & & $\begin{array}{l}-0.097^{* *} \\
(0.038)\end{array}$ & $\begin{array}{l}-0.218 \\
(0.137)\end{array}$ \\
\hline$R O A \_P R E$ & & $\begin{array}{l}-0.527^{* * *} \\
(0.092)\end{array}$ & \\
\hline$R O E \_P R E$ & & & $\begin{array}{l}-0.725^{\text {*** }} \\
(0.111)\end{array}$ \\
\hline INTERCEPT & & $\begin{array}{l}-0.001 \\
(0.137)\end{array}$ & $\begin{array}{c}0.269 \\
(0.620)\end{array}$ \\
\hline Industry fixed effects & & Included & Included \\
\hline $\begin{array}{l}\text { Observations } \\
\text { R-squared }\end{array}$ & & $\begin{array}{c}800 \\
0.322\end{array}$ & $\begin{array}{c}800 \\
0.292\end{array}$ \\
\hline
\end{tabular}

This table reports the regression results on the impact of ethical CSR on CFP using an alternative sample. The sample comprises 400 observations for firms with increased numbers of CSR strengths from the pre-crisis period (2006 and 2007) to the crisis period (2008 and 2009) and 400 firm-years for firms with unchanged or decreased numbers of CSR strengths from the pre-crisis period to the crisis period. The dependent variable in column (1) is the change in $R O A$ from the pre-crisis period (2006 and 2007) to the post-crisis period (2010 and 2011). The dependent variable in column (2) is the change in $R O E$ from the pre-crisis period to the post-crisis period. Detailed variable definitions are in Appendix. Standard errors, displayed in parentheses below coefficient estimates, are adjusted for heteroscedasticity. ${ }^{* * *}\left({ }^{* *}\right)\left({ }^{*}\right)$ indicates significance at the $1 \%(5 \%)(10 \%)$ level, using two-tailed tests. 
Table 6 The Impact of Ethical CSR in Employee Relations and Diversity on Firm Financial Performance-Alternative Sample

\begin{tabular}{|c|c|c|c|c|}
\hline Dependent Variable & $\begin{array}{c}(1) \\
\Delta R O A \\
\end{array}$ & $\begin{array}{c}(2) \\
\Delta R O E \\
\end{array}$ & $\begin{array}{c}(3) \\
\triangle R O A \\
\end{array}$ & $\begin{array}{c}(4) \\
\Delta R O E \\
\end{array}$ \\
\hline ETHIC_STR_EMP & $\begin{array}{l}0.015^{* *} \\
(0.007)\end{array}$ & $\begin{array}{c}0.001 \\
(0.030)\end{array}$ & & \\
\hline ETHIC_STR_DIV & & & $\begin{array}{c}0.008 \\
(0.008)\end{array}$ & $\begin{array}{c}0.033 \\
(0.031)\end{array}$ \\
\hline HHI_PRE & $\begin{array}{c}0.008 \\
(0.330)\end{array}$ & $\begin{array}{c}0.326 \\
(0.600)\end{array}$ & $\begin{array}{c}0.122 \\
(0.291)\end{array}$ & $\begin{array}{c}0.190 \\
(0.721)\end{array}$ \\
\hline$S I Z E_{-} P R E$ & $\begin{array}{c}0.004 * \\
(0.002)\end{array}$ & $\begin{array}{c}0.015 \\
(0.012)\end{array}$ & $\begin{array}{c}0.005^{*} \\
(0.003)\end{array}$ & $\begin{array}{c}0.031^{* * *} \\
(0.011)\end{array}$ \\
\hline$M B \_P R E \_P R E$ & $\begin{array}{c}0.002 \\
(0.002)\end{array}$ & $\begin{array}{c}0.002 \\
(0.010)\end{array}$ & $\begin{array}{l}0.006^{* * *} \\
(0.002)\end{array}$ & $\begin{array}{l}0.027^{* * *} \\
(0.007)\end{array}$ \\
\hline$L E V \_P R E$ & $\begin{array}{l}-0.014 \\
(0.029)\end{array}$ & $\begin{array}{l}-0.245 \\
(0.155)\end{array}$ & $\begin{array}{c}0.026 \\
(0.040)\end{array}$ & $\begin{array}{l}-0.215 \\
(0.205)\end{array}$ \\
\hline CASH_PRE & $\begin{array}{l}-0.074 \\
(0.065)\end{array}$ & $\begin{array}{l}-0.243 \\
(0.155)\end{array}$ & $\begin{array}{l}-0.076 \\
(0.047)\end{array}$ & $\begin{array}{l}-0.169 \\
(0.195)\end{array}$ \\
\hline$R O A \_P R E$ & $\begin{array}{l}-0.523^{* * *} \\
(0.128)\end{array}$ & & $\begin{array}{l}-0.685^{* * *} \\
(0.124)\end{array}$ & \\
\hline$R O E \_P R E$ & & $\begin{array}{l}-0.636^{* * *} \\
(0.171)\end{array}$ & & $\begin{array}{l}-0.912^{* * *} \\
(0.093)\end{array}$ \\
\hline INTERCEPT & $\begin{array}{c}0.011 \\
(0.046)\end{array}$ & $\begin{array}{l}-0.015 \\
(0.119)\end{array}$ & $\begin{array}{l}-0.012 \\
(0.044)\end{array}$ & $\begin{array}{l}-0.168^{*} \\
(0.093)\end{array}$ \\
\hline Industry fixed effects & Included & Included & Included & Included \\
\hline Observations & 456 & 456 & 356 & 356 \\
\hline R-squared & 0.365 & 0.282 & 0.495 & 0.528 \\
\hline
\end{tabular}

This table reports the regression results on the impact of ethical CSR strengths in employee relations on CFP in column (1) and (2) and the impact of ethical CSR strengths in diversity on CFP in column (3) and (4) using an alternative sample. The employee relation sample comprises 228 observations for firms with increased numbers of CSR strength in employee relations from the pre-crisis period (2006 and 2007) to the crisis period (2008 and 2009) and 228 observations for firms with unchanged or decreased numbers of CSR strength in employee relations from the pre-crisis period to the crisis period. The diversity sample comprises 178 observations for firms with increased numbers of CSR strength in diversity from the pre-crisis period to the crisis period and 178 observations for firms with unchanged or decreased numbers of CSR strength in diversity from the pre-crisis period to the crisis period. The dependent variable in column (1) and (3) is the change in $R O A$ from the pre-crisis period to the post-crisis period. The dependent variable in column (2) and (4) is the change in $R O E$ from the pre-crisis period to the postcrisis period. Detailed variable definitions are in Appendix. Standard errors, displayed in parentheses below coefficient estimates, are adjusted for heteroscedasticity. ${ }^{* * *}\left({ }^{* *}\right)\left({ }^{*}\right)$ indicates significance at the $1 \%(5 \%)(10 \%)$ level, using two-tailed tests. 